\title{
PERSPEKTIF OPORTUNISTIK DAN EFISIEN DALAM FENOMENA MANAJEMEN LABA
}

\author{
EARNINGS MANAGEMENT FROM OPPORTUNISTIC AND EFFICIENT \\ PERSPECTIVES
}

\author{
Oleh: \\ Denies Priantinah \\ Staf Pengajar Jurusan Pendidikan Akuntansi Universitas Negeri Yogyakarta \\ denies_priantinah@uny.ac.id
}

\begin{abstract}
Abstrak
Managemen laba bisa muncul dari adanya problem asimetri informasi dan konflik keagenan. Kondisi asimetri informasi ini akan eksis apabila kepemilikan ekuitas terpisah dari operasi perusahaan dan manager memiliki keunggulan atas informasi dibandingkan pemegang saham. Di sisi lain kondisi pasar tidak sempurna mampu menciptakan lingkungan bagi manager untuk melakukan diskresi akuntansi yang dilakukan untuk kepentingan manager yang dibebankan pada pemegang saham. Namun, di sisi lain managemen laba juga mampu menciptakan kesempatan bagi manager untuk menggunakan diskresi akuntansi untuk mengkomunikasikan kinerja perusahaan terkait dengan informasi dengan cara yang memadai kepada para investor.

Salah satu alasan yang mendasari fenomena managemen laba ini terus eksis dan dilakukan oleh banyak perusahaan karena adanya sisi baik dari managemen laba. Sisi baik dari managemen laba bisa ditinjau dari sudut pandang kontrak efisien dan pelaporan keuangan. Dari perspektif kontrak efisien dalam Positive Accounting Theory, tingkat managemen laba bisa dianggap baik karena mampu meningkatkan efisiensi kontrak, alih-alih dilakukan sebagai bentuk perilaku oportunistik managemen. Kontrak yang efisien, memberikan keleluasaan kemampuan bagi manager untuk mengelola laba dalam kontrak yang rigid dan incomplete. Dalam kondisi ini, interpretasi terhadap perilaku managemen laba yang dilakukan manager dalam hal skema bonus, perjanjian hutang dan biaya politik harus dilakukan secara hati-hati, karena perilaku tersebut bisa mengambil bentuk sebagai perilaku yang efisien atau oportunis.

Perspektif perilaku oportunistik atas managemen laba, memiliki sudut pandang bahwa manager menggunakan asimetri informasi antara pihak eksternal dan internal perusahaan untuk memaksimisasi utilitas mereka terkait dengan kontrak kompensasi, kontrak hutang dan regulasi. Investor kemudian dikelabuhi dengan laporan informasi yang tidak reliabel. Manfaat dari manajemen laba ditengarai diperoleh jika manajer melakukan manajemen laba demi kepentingan entitas, khususnya pemegang saham. Fenomena ini banyak ditemui dalam hal political cost dan debt covenant. Penggunaan manajemen laba yang mengedepankan kepentingan perusahaan ini masuk dalam perspektif efisien. Dua sisi manajemen laba, yakni perspektif efisien dan perspektif oportunistik terjadi dalam banyak perusahaan. Usaha untuk menekan perilaku manajemen laba tentunya kemudian sedikit banyak harus memperhatikan dampak yang muncul atas perilaku tersebut, apakah dilakukan dalam kepentingan pribadi manajer atau untuk kepentingan entitas.
\end{abstract}

Kata kunci: Manajemen Laba, Perspektif Oportunistik

\begin{abstract}
Earnings management could arise from the problem of information asymmetry and agency conflicts. This information asymmetry condition will exist when the manager has more or better information than the stockholders which lead to the transactions to go awry, or even market faliure in the worst case. Therefore, earnings management phonemena attracts attention from many parties who has interest in corporation. The imperfect market conditions are capable of creating an environment
\end{abstract}




\section{Jurnal Pendidikan Akuntansi Indonesia, Vol. XIV, No. 2, Tahun 2016}

Denies Priantinah

$1-12$

for the manager to make discretionary accounting is done for the benefit manager charged to shareholders. However, on the other hand profit management is also able to create an opportunity for managers to use accounting discretion to communicate information related to the company's performance in a manner sufficient to investors. Thus the behavior of earnings management has two perspectives - the opportunistic and efficient perspective.

One of the reasons underlying earnings management continues to exist and conducted by many companies is for their efficient side of earnings management. This perspective of earnings management can be derrived from efficient contracts in the Positive Accounting Theory, which can increase the efficiency of the contract. Efficient contract are enabling managers to manage earnings in the contract which are rigid and incomplete. In this condition, the interpretation of the behavior of earnings management performed manager in terms of bonus schemes, debt covenants and political costs must be done carefully, because such behavior could take perspective as efficient or opportunistic behavior. In the perspective of the contract, it can be produced from the opportunistic behavior of managers by identifying the tendency of managers to use management profit maximization in order to perform a bonus plan. Perspective of opportunistic behavior on earnings management, has a viewpoint that the manager uses the information asymmetry between the external and internal parties to maximize the utility of their related compensation contracts, debt contracts and regulations. Investors then deceived by reports unreliable information.

Earnings managemen can be classified as ethical or not, often depends on the viewing angle associated with which parties are benefited. Earnings management which is done solely to advance the interests of managers are often classified in opportunistic perspective. This opportunistic perspective will in turn weigh on other parties such as shareholders and categorized as a bad thing. Earnings management in this perspective often appears in Bonus Plan. On the other hand, the phenomenon of earnings management that continues to exist in the business world because of this can be viewed as efficient perspective. Benefits of earnings management is considered obtained if earnings management conducted in the interests of the entity, particularly shareholders. This phenomenon is ubiquitous in terms of political cost and debt covenants. The use of earnings management that promotes the interests of companies have entered into an efficient perspective. Two sides of earnings management, i.e. the perspective of efficient and opportunistic perspective happened in many companies. Attempts to suppress earnings management behavior should certainly then need more attention to the impact that arose over the behavior, whether done in the manager's personal interests or in the interests of the entity.

Kata Kunci: Earning Management, Opportunistic Perspectives

\section{PENDAHULUAN}

Manajemen laba merupakan tindakan yang dilakukan oleh manajer sebuah entitas bisnis. Eksistensi manajemen laba dalam sebuah hubungan agen dan prinsipal tidak akan lepas dari fungsi pelaporan keuangan perusahaan. Meskipun bagi sebagian pihak, perilaku ini dianggap tidak etis, namun fenomena yang terus berlanjut ini dianggap mampu memberikan manfaat bagi pihak tertentu, dan di sisi lain menimbulkan kerugian. Schipper (1998) menyatakan managemen laba sebagai tindakan manager yang dilakukan sebagai intervensi dalam proses pelaporan keuangan pada pihak eskternal. Tindakan ini dilakukan dengan intensi untuk memperoleh keuntungan pribadi bagi manager dan pemegang saham.

Keuntungan bagi pemegang saham akan dicapai apabila managemen laba dipergunakan sebagai sarana untuk memberikan sinyal dari manager ke pemegang saham terkait dengan informasi privat yang dimiliki manager (Healy dan Palepu, 1993). Keuntungan lain yang diperoleh pemegang saham adalah jika melalui managemen laba tersebut, perusahaan bisa mengurangi biaya politik yang dihadapinya (Watts \& Zimmerman, 1986). Sedangkan keuntungan pribadi yang diperoleh manager dengan melakukan managemen laba adalah untuk menaikkan kompensasi (Healy,1985). Keuntungan 
managemen laba bagi manager dilakukan juga untuk mengurangi kemungkinan terjadi pemecatan ketika manager memiliki kinerja yang rendah (Weisbach, 1988), namun di sisi lain tindakan ini akan merugikan pemegang saham. Healy dan Wahlen (1998) menyatakan dalam penelitiannya, bahwa motivasi yang mendasari managemen laba terbagi menjadi tiga jenis. Pertama adalah motivasi yang ditunjukkan dari pasar modal terkait dengan return saham. Kedua, berupa motivasi kontrak, baik yang berupa kontrak hutang maupun kontrak kompensasi managemen. Sedangkan yang ketiga berupa motivasi regulasi, yaitu motivasi untuk menghindari biaya politik.

\section{Managemen Laba ditinjau dari Sudut Pandang Oportunistik dan Efisien dalam} Positive Accounting Theory

Managemen laba bisa muncul dari adanya problem asimetri informasi dan konflik keagenan. Kondisi asimetri informasi ini akan eksis apabila kepemilikan ekuitas terpisah dari operasi perusahaan dan manager memiliki keunggulan atas informasi dibandingkan pemegang saham. Di sisi lain kondisi pasar tidak sempurna mampu menciptakan lingkungan bagi manager untuk melakukan diskresi akuntansi yang dilakukan untuk kepentingan manager yang dibebankan pada pemegang saham. Namun, di sisi lain managemen laba juga mampu menciptakan kesempatan bagi manager untuk menggunakan diskresi akuntansi untuk mengkomunikasikan kinerja perusahaan terkait dengan informasi dengan cara yang memadai kepada para investor (Trueman \& Titman, 1988; Dye, 1988; Schipper, 1989). Dengan demikian perilaku Managemen laba memiliki dua perspektif yang saling berdampingan, yaitu perspektif oportunistik dan perspektif efisien.

\section{Sisi Baik Managemen Laba sebagai Perilaku Efisien}

Salah satu alasan yang mendasari fenomena managemen laba ini terus eksis dan dilakukan oleh banyak perusahaan karena adanya sisi baik dari managemen laba. Sisi baik dari managemen laba bisa ditinjau dari sudut pandang kontrak efisien dan pelaporan keuangan. Dari perspektif kontrak efisien dalam Positive Accounting Theory, tingkat managemen laba bisa dianggap baik karena mampu meningkatkan efisiensi kontrak, alih-alih dilakukan sebagai bentuk perilaku oportunistik managemen. Kontrak yang efisien, memberikan keleluasaan kemampuan bagi manager untuk mengelola laba dalam kontrak yang rigid dan incomplete. Dalam kondisi ini, interpretasi terhadap perilaku managemen laba yang dilakukan manager dalam hal skema bonus, perjanjian hutang dan biaya politik harus dilakukan secara hati-hati, karena perilaku tersebut bisa mengambil bentuk sebagai perilaku yang efisien atau oportunis.

Managemen laba bisa menjadi alat untuk menyampaikan informasi internal perusahaan ke pasar yang pada gilirannya diharapkan mampu memperkuat harga saham karena mampu merefleksikan prospek masa depan perusahaan dengan lebih baik. Dari sudut pandang signalling theory, fenomena managemen laba merupakan bentuk perilaku di mana manager akan mengelola laba untuk mengungkapkan informasi internal terkait dengan prospek perusahaan sehingga akan berfungsi sebagai proses pemberian informasi kepada pasar (signalling mechanism). Dengan managemen laba ini, manager akan mampu untuk mempengaruhi harga. Pengaruh terhadap harga saham ini bisa dilakukan melalui managemen laba yang menciptakan laba yang merata (smooth) dan bertumbuh sepanjang waktu. Managemen laba mampu menjadi mekanisme sinyal dimana informasi internal perusahaan bisa disampaikan kepada pihak eksternal perusahaan. Sejumlah studi telah memodelkan asimetri informasi dan menetapkan managemen laba sebagai perilaku ekuilibrium rasional seperti yang telah dilakukan oleh: Ronen \& Sadan 
(1980), Demski et. al.(1984), Lambert, (1984), Dye (1988), Trueman \& Titman (1988), Suh (1990), Wang \& Williams (1994), Chaney et al. (1995), Hunt et al.(1997), Bartov et al.( 2002) dan Lev (2003). Penelitian-penelitian tersebut mendokumentasikan bukti adanya penggunaan managemen laba sebagai mekanisme sinyal untuk memfasilitas komunikasi yang efisien antara manager dan pengguna informasi. Sinyal yang diberikan melalui managemen laba tersebut dipergunakan untuk meningkatkan relevansi nilai dari pelaporan keuangan dan memperkuat kemampuan investor dalam memprediksi kinerja perusahaan.

Penelitian-penelitian penggunaan managemen laba sebagai alat komunikasi dari pihak internal ke esternal, berhasil mengidentifikasi bahwa managemen laba merupakan sesuatu hal yang diinginkan oleh pemegang saham. Dalam kondisi tersebut, investor menginginkan manager melakukan managemen laba untuk dua alasan: (1). Manager bisa mengurangi biaya modal melalui aliran laba yang lebih merata dan bisa diprediksi. (2). Aliran laba yang lebih stabil mempengaruhi persepsi calon investor terhadap nilai perusahaan yang lebih baik (Dye, 1988). Selain itu, karena pemegang saham yang sekarang akan menjual saham yang mereka miliki kepada pemegang saham di masa depan, maka manager yang melakukan managemen laba akan bertindak untuk kepentingan pemegang saham yang sekarang supaya bisa meningkatkan harga saham dan memiliki insentif untuk mengelola laba dengan cara maksimisasi harga jual saham. Hal ini dibuktikan melalui penelitian yang dilakukan Easton dan Zmijewski (1989) serta Chaney dan Lewis (1995).

Penelitian yang dilakukan oleh Scott (1997) mencatat bahwa managemen laba bisa juga dilakukan oleh manager dengan tujuan kontrak yang efisien. Kontrak efisien mengasumsikan bahwa managemen laba bisa digunakan untuk memfasilitasi pengendalian internal dan pembuatan keputusan. Kontrak efisien yang bisa difasilitas diantaranya adalah proses monitoring terhadap manager, membatasi perilaku oportunistik manager, meminimalkan pajak yang harus dibayarkan oleh perusahaan, mereduksi kontrak hutang yang berbiaya tinggi dan meminimalkan biaya kontrak. Dalam kasus kontrak kompensasi dan kontrak hutang, pemilik dan pemberi pinjaman akan mengantisipasi insentif yang mungkin diperoleh manager karena mengelola laba. Antisipasi ini dilakukan karena dalam managemen laba bisa terjadi transfer kesejahteraan antara pihak yang terlibat dalam kontrak.

Kontrak yang efisien didisain dengan mempertimbangkan ekspektasi prinsipal dan pemberi pinjaman atas perilaku oportunisme manager, dengan memasukkan antisipasi dampak perilaku oportunistik manager ke dalam kontrak. Christie dan Zimmerman (1994) menyatakan bahwa oportunisme manager yang diekspektasikan telah dipertimbangkan dan dimasukkan dalam kontrak yang efisien. Dengan demikian hanya oportunisme manager yang tidak diekspektasikan yang merupakan tindakan yang tidak efisien. Dalam kondisi ini, maka managemen laba bisa dijadikan alat bagi manager untuk memperkuat efisiensi kontrak. Christie dan Zimmerman (1994) mengivestigasi frekuesi perusahaan yang dideteksi melakukan managemen laba dengan pola income increasing untuk tujuan maksimisasi laba. Penelitian tersebut menemukan bahwa diskresi yang meningkatkan laba tidak digunakan untuk menghindari kemungkinan pengambilalihan perusahaan ketika terjadi peristiwa akuisisi. Penelitian tersebut menyimpulkan bahwa managemen laba dengan tujuan kontrak efisien bukanlah perilaku oportunistik seperti yang sebelumnya dipikirkan.

Poin yang menarik yang pernah diteliti mengenai managemen laba adalah adanya korelasi antara kontrak yang efisien dengan mekanisme signal. Decow (1994) menyatakan bahwa dengan pasar modal yang efisien, laba menjadi kurang 
berkorelasi dengan return saham dibandingkan dengan aliran kas apabila komponen akrual dari laba sebagian besar merupakan hasil tindakan manipulasi yang bersifat oportunistik. Alternatif yang lain, apabila akrual merefleksikan kontrak yang efisien, maka laba seharusnya lebih berkorelasi dengan return saham daripada dengan aliran kas. Konfirmasi terkait dengan alternatif kedua mengarahkan kita pada masalah, apakah terdapat interaksi antara kontrak yang efisien dengan sinyal informasi? Apabila perilaku managemen laba yang dilakukan perusahaan diinterpretasikan dengan insentif kontrak atau motif pasar, apakah hal tersebut konsisten? Subramanyam's (1996) meneliti apakah hal tersebut mungkin terjadi. Penelitian tersebut menemukan bahwa akrual diskresioner sangat berkaitan dengan kinerja laba masa depan, lebih jauh lagi pasar saham akan bereaksi secara positif terhadap diskresi laba. Implikasi dari penemuan ini adalah perilaku diskresioner managemen melalui akrual meningkatkan persistensi laba dan sekaligus meningkatkan kemampuan laba sekarang dalam memberikan sinyal prospek masa depan perusahaan. Walaupun penelitian tersebut tidak menginterpretasikan reaksi pasar yang positif terhadap munculnya kontrak yang efisien, namun berdasarkan pasar efisien, akan sulit untuk mengobservasi adanya reaksi pasar positif apabila diskresi tersebut dibuat secara oportunistik. Hal ini menunjukkan adanya kemungkinan bahwa sinyal informasi terkait dengan level efisiensi kontrak.

Perilaku managemen laba telah banyak didokumentasikan dalam literatur akuntansi dan telah banyak pula dilakukan eksplorasi melalui penelitian. Managemen laba bisa dikategorikan memiliki sisi yang baik. Alasan yang mendasari argumen ini adalah:

1. Dalam hal ini kita bisa melihat bahwa manjemen laba berupakan hal yang baik apabila kita membahasnya dalam konteks contracting theory. Teori ini menyatakan bahwa managemen laba bisa diantisipasi oleh prinsipal dengan menerapkan kontrak bonus yang dinegosiasikan. Dengan demikian adanya perilaku manjemen laba yang mampu diantisipasi melalui kontrak yang efisien diharapkan mampu menurunkan contracting cost untuk menghadapi kontrak yang rigid dan incomplete.

2. Managemen laba juga dianggap sebagai tindakan yang efisien karena mampu mengungkap informasi internal kepada investor. Hal ini dianggap sebagai hal yang masih kontroversial. Diskusi mengenai manjemen laba dari sisi ini mengatakan bahwa managemen laba bisa dipandang sebagai perluasan dari proses akrual. Yaitu apabila akrual memperhalus aliran kas untuk menghasilkan ukuran yang lebih berguna untuk mengukur kinerja kuartalan atau tahunan. Mengapa managemen laba tidak dapat digunakan untuk memperhalus akrual tahunan yand didasarkan pada laba untuk menghasilkan pengukuran daya persistensi laba multi tahun yang lebih berguna? Ukuran ini diharapkan mampu membantu investor untuk memprediksi kinerja masa depan perusahaan dengan lebih baik. Dimana hal tersebut adalah tujuan utama dari pelaporan keuangan.

Konsep ini mengarah pada hambatan komunikasi. Penelitian Schipper (1989), Demski dan Sappington (1987, 1990) mengeksplorasi konsep bahwa managemen laba memiliki sisi baik karena memiliki peran untuk mengungkap hambatan informasi dari pihak internal perusahaan ke investor. Penelitian Stocken dan Verrecchia (2004) mendukung bahwa masalah potensial apabila managemen laba digunakan sebagai sarana untuk mengungkap informasi internal 
adalah reliabilitasnya. Dalam hal ini manjemen laba membuat informasi laporan keuangan memiliki reliabilitas yang rendah, karena informasi tersebut belum diakui dalam sistem akuntansi. Hanya apabila perusahaan menghadapi ketidakpastian yang tinggi, dengan informasi internal yang jumlahnya tinggi maka informasi yang diungkap oleh managemen maka informasi yang dikeluarkan dengan managemen laba bisa berguna. Hasil penelitian Subramanyam (1996) mendukung sisi baik dari managemen laba. Xie's (2001), Liu et. all. (1997). Barth et.al. (1999) juga mendukung adanya sisi baik dari managemen laba, pada level managemen laba mampu menghasilkan pola peningkatan laba yang stabil.

\section{Sisi Buruk Managemen Laba sebagai Perilaku Oportunistik.}

Selain teori dan bukti tentang penggunaan managemen laba yang efisien, terdapat juga bukti bahwa managemen laba adalah tindakan buruk manager. Dalam perspektif kontrak, hal ini dapat dihasilkan dari perilaku manager yang oportunistik dengan mengindentifikasi kecenderungan manager untuk menggunakan managemen laba guna melakukan maksimisasi bonus. Perspektif perilaku oportunistik atas managemen laba, memiliki sudut pandang bahwa manager menggunakan asimetri informasi antara pihak eksternal dan internal perusahaan untuk memaksimisasi utilitas mereka terkait dengan kontrak kompensasi, kontrak hutang dan regulasi. Investor kemudian dikelabuhi dengan laporan informasi yang tidak reliabel. Watts dan Zimmerman (1978) pertama kali menggunakan pendekatan oportunistik dalam menjelaskan perilaku diskresi atas laba yang dilaporkan untuk mempengaruhi hasil kontraktual dan mempengaruhi transfer kesejahteraan. Penelitian yang serupa juga dilakukan oleh Guay et al. (1996),
Christensen et al. (1999), and Bradshaw et al. (2001).

Sisi oportunistik managemen laba menggambarkan keinginan manager untuk mempengaruhi transfer kesejahteraan antara pihak-pihak yang terikat dalam kontrak. PAT menyatakan bahwa pemilik perusahaan mengharapkan manager untuk melakukan diskresi atas kepentingan pemegang saham dan memasukan hal ini dalam pertimbangan penetapan kompensasi manager. Ketika nilai kompensasi manager termasuk diskresi manager yang diharapkan oleh pemegang saham, kontrak kompensasi ini akan mengendalikan ekspektasi manager sehingga meningkatan level diskresi itu sendiri. Scott (1997) menyatakan bahwa diskresi manager yang tidak diharapkan ini akan berdampak pada kerugian bersih kesejahteraan pemegang saham secara agregat. Dalam hubungan kontraktual, manager merupakan pihak yang lebih risk averse dibandingkan dengan pihak lain. Subyek memiliki keterbatasan dalam kontrak tersebut, sehingga akan berusaha untuk memaksimalkan kesejahteraan pribadinya.

Disamping arguman adanya sisi baik dari managemen laba, banyak hal yang menunjukkan pula bahwa managemen laba memiliki sisi buruk. Hal ini didasarkan pada fenomena yang terjadi bahwa managemen laba banyak disalahgunakan pada banyak kasus di perusahaan. Penelitian menunjukkan bahwa managemen cenderung untuk menyediakan banyak biaya yang berlebihan dan tidak biasa, biaya yang tidak muncul secara berulang untuk membuat laba masa depan di bank. Sementara laba masa depan terbenam dalam operasi. Hal ini membuat investor kesulitan untuk mendiagnosa alasan peningkatan laba pada periode berikutnya.

\section{Membedakan Sudut Pandang Oportunistik dan Efisien dalam Positive Accounting Theory}

Hipotesis dalam Positive Accounting

Theory, menggunakan sudut pandang 
oportunistik. Pandangan ini mengasumsikan bahwa manager memilih kebijakan akuntansi untuk maksimisasi utilitas ekspektasian (expected utility) agen relatif terhadap remunerasi yang mereka terima (bonus plan hypothesis), kontrak hutang (debt covenant hypothesis) dan biaya politik (political cost). Hipotesis tersebut juga bisa dinyatakan dalam bentuk efisien. Dalam sudut pandang ini berasumsi bahwa kontrak kompensasi dan sistem pengendalian internal, termasuk monitoring oleh dewan komisaris, membatasi oportunistik manager dan memotivasi manager untuk memilih kebijakan akuntansi yang meminimisasi biaya modal perusahaan dan biaya kontrak.

Dua bentuk perspektif managemen laba, berupa oportunistik dan efisien berdasarkan PAT bisa memiliki prediksi yang serupa. Misalnya dalam bonus plan hypothesis, manager bisa jadi akan memilih amortisasi garis lurus daripada saldo menurun. Dampak dari pilihan ini adalah meningkatnya angka laba yang pada gilirannya akan meningkatkan angka remunerasi manager. Dari sudut pandang ini, maka manager dianggap oportunistik. Namun kebijakan yang sama bisa jadi dipilih dalam bonus plan hypothesis tetapi pada sudut pandang alasan efisiensi. Misalkan amortisasi garis lurus merupakan ukuran terbaik dari opportunity cost perusahaan dalam penggunaan aset tetapnya. Amortisasi garis lurus menghasilkan laba yang dilaporkan dengan mengukur kinerja perusahaan secara lebih baik. Hasilnya kebijakan ini bisa jadi secara efisien lebih memotivasi manager (dengan tujuan pertama adalah bonus) relatif terhadap kebijakan amortisasi yang lain.

Dari penjelasan pilihan managemen akan kebijakan akuntansi, maka akan sulit untuk mengatakan apakah observasi atas kebijakan akuntansi yang dipilih perusahaan dikendalikan oleh motif oportunistik atau efisiensi. Dalam hal ini tanpa mampu untuk membedakan kemungkinan ini, maka akan sulit untuk mengatakan bahwa proses dari pilihan kebijakan akuntansi bisa dipahami.
Riset-riset pada PAT menghadapi masalah ini. Beberapa penelitian sebelumnya pernah mencoba mengkaji sudut pandang efisien dan oportunistik managemen laba dalam Positive Accounting Theory (Scott, 2007: pp 284).

Penentuan pengaruh relatif managemen laba sebagai suatu tindakan yang oportunis atau efisien, membutuhkan definisi atas klasifikasi tindakan tersebut. Perusahaan dikenal sebagai nexus of contract, dimana pihak-pihak yang terkait melakukan kontrak dan sepakat untuk mendistribusikan aliran kas perusahaan diantara pihak-pihak yang terikat kontrak tersebut. Dengan adanya kontrak tersebut setiap pihak berusaha untuk meminimalkan biaya agensi yang timbul (Jensen dan Meckling, 1976). Apabila setiap pihak dalam perusahaan berusaha untuk menyusun kontrak yang bisa mentransfer kekayaan dari pihak lain kepada dirinya, maka tiap kepentingan pihak lain akan membatasi terjadinya transfer kekayaan tersebut. Misalnya, apabila manager menggunakan metode akuntansi tertentu, maka selama umur kontrak tersebut, manager akan dibatasi dengan penggunaan set prosedur akuntansi yang diperkenankan. Ketika kontrak dilakukan, maka manager melakukan keputusan terkait dengan akuntansi dan keputusan lain, yang dikombinasikan dengan kondisi alamiah lainnya akan menghasilkan aliran kas untuk memenuhi klaim pihak-pihak yang memiliki kontrak dalam perusahaan. Dengan keadaan dimana kondisi masa depan berubah, serta manager memiliki informasi yang lebih memadai terkait dengan prosedur akuntansi mana yang akan lebih memaksimalkan nilai perusahaan maka akan optimal apabila manager memiliki diskresi atas pemilihan metode akuntansi di masa depan (Demski et.al 1984).

Ketika melibatkan diri pada awal kontrak, para pemegang klaim menyadari bahwa perilaku manager di masa depan berpotensi untuk mentransfer kesejahteraan antar pemegang klaim. Adanya informasi 
asimetri dan biaya monitoring yang tinggi akan membuat pihak-pihak yang memiliki klaim terhadap perusahaan sulit untuk melakukan pengawasan secara sempurna terhadap perilaku manager. Oportunisme managerial ekspektasian adalah kerugian nilai yang harus ditanggung oleh pihak lain dalam kontrak yang disebabkan oleh manager berdasarkan biaya kontrak yang terjadi. Berdasarkan kontrak yang ada maka pemegang saham dan obligasi yang memperoleh diskon atas harga sekuritas akan terproteksi dari tindakan managerial yang berpotensi menurunkan return yang diperoleh mereka dimasa depan. Dalam hal ini pemegang saham terproteksi atas harga terhadap oportunisme yang dilakukan manager.

Keputusan manager, termasuk pemilihan atas metode akuntansi tertentu merupakan tindakan yang mampu meningkatkan kesejahteraan pribadi di atas beban pihak lain yang terikat kontrak. Namun, karena pemegang klaim yang rasional terlindungi oleh harga terhadap oportunisme yang akan terjadi maka manager akan memiliki insentif untuk meminimalkan oportunisme ekspektasian. Dalam hal ini maka oportunisme merupakan hal yang efisien. Maksimisasi nilai perusahaan yang akan memunculkan oportunisme akan muncul apabila biaya marginal atas monitoring sama dengan reduksi marginal biaya atas oportunisme manager. Sedangkan tindakan manager akan disebut efisien apabila mampu meningkatkan kesejahteraan agregat semua pihak yang terikat kontrak, termasuk manager atas semua biaya kontrak yang ditimbulkan.

Oportunisme akan muncul ketika keputusan manager akan meningkatkan kesejahteraan manager tetapi tidak diikuti dengan kekayaan bersih secara agregat. Oportunisme manager akan timbul apabila (1) Kondisi sistem pengendalian perusahaan mampu memberi celah bagi manager untuk melakukan tindakan yang memperkaya dirinya sendiri. (2) Adanya kesalahan pada saat perjanjian kontrak dilakukan. Oportunisme berarti bahwa manager manager melakukan tindakan mentransfer kesejahteraan dari pemegang saham atau pemegang hutang tanpa menimbulkan kenaikan kesejahteraan bersih secara agregat.

Metode akuntansi bisa dikatakan efisien apabila maksimisasi nilai perusahaan memiliki karakteristik berikut:

1. Mekanisme pembuatan keputusan dan pengendalian di dalam perusahaan, seperti alokasi biaya, transfer pricing, penganggaran modal, perencanaan, penilaian kinerja, dan kompensasi akan dipengaruhi oleh pemilihan metode akuntansi. Keputusan dan sistem pengendalian ini saling terkait, sehingga maksimisasi nilai perusahaan membutuhkan pemilihan metode akuntansi yang mengoptimalkan keputusan tersebut (Ball, 1989) dan Christie et.al. (1993).

2. Pertimbangan efisiensi juga didasarkan atas pertimbangan pajak. Contoh dalam hal ini adalah pemilihan metode persediaan untuk meminimalkan nilai sekarang dari pajak. Biasanya efisiensi berupa pilihan metode akuntansi yang menurunkan angka laba perusahaan. Namun dalam kasus kerugian pembayaraan pajak yang harus dibawa dimuka, maka perusahaan akan memilih menggunakan metode yang mampu meningkatkan laba.

3. Jensen (1988) menyatakan bahwa ketika industri memiliki kelebihan kapasitas dan tingkat pertumbuhan menurun, maka pilihan untuk merger memberikan kesempatan pada perusahaan untuk menghadapi biaya yang lebih rendah daripada harus melakukan kebangkrutan. Perusahaan yang menjadi target pengambilalihan merupakan perusahaan yang memiliki kinerja 
yang rendah akan membuat manager memiliki motif oportunisme. Dalam kondisi ini, perusahaan akan mengalami kesulitan keuangan dan menghadapi konstrain dengan pemberi hutang, maka manager akan memilih menggunakan metoda akuntansi yang mampu meningkatkan angka laba untuk mereduksi batasan kontrak dengan para pemberi hutang tersebut. Apabila metode yang mampu menaikkan laba ini bisa mengurangi cost of financial distress, maka perilaku tersebut digolongkan dalam efisien dan bukannya oportunis.

Sedangkan metode akuntansi bisa dikatakan oportunistik apabila maksimisasi nilai perusahaan memiliki karakteristik berikut:

1. Manager yang mendahulukan kepentingan pribadinya akan berusaha untuk meningkatkan kompensasi mereka di atas kontribusi yang mereka berikan ke perusahaan. Peran Dewan komisaris, auditor, kompensasi berbasis saham, kompetisi dalam pasar produk perusahaan, kompetisi dari manager lain, dan pengendalian internal akan membatasi kepentingan pribadi manager tersebut. Tetapi semua alat tersebut membutuhkan biaya yang cukup tinggi untuk mampu membatasi sifat oportunis manager.

2. Metoda akuntansi yang oportunis didefinisikan sebagai tindakan manager yang memiliki intensi untuk meningkatkan angka laba perusahaan di atas yang jumlah yang diekspektasikan. Manager yang oportunistik diprediksi akan melakukan tindakan ini berdasarkan dua alasan, (1). Meningkatkan kompensasi berdasarkan skema kompensasi yang berbasis angka laba akuntansi. (2). Menghindarkan kemungkinan penggantian manager karena adanya kinerja yang buruk Holthousen dan Leftwich (1983) menyatakan dengan kontrak yang berbiaya tinggi, program kompensasi managemen memberikan insentif untuk bagi manager untuk memilih metode akuntansi yang tidak memaksimalkan nilai perusahaan. Di sisi lain manager juga bisa memilih metode akuntansi yang mampu meningkatkan laba perusahaan (Healy, 1985).

\section{SIMPULAN}

Fenomena manajemen laba merupakan fenomena yang umum terjadi dalam sebuah entitas bisnis. Fenomena ini apakah akan dipandang sebagai hal yang etis atau tidak, seringkali bergantung pada sudut pandang terkait dengan pihak manakah yang diuntungkan dan memetik manfaat atas fenomena manajemen laba tersebut. Manajemen laba yang dilakukan sematamata demi mengedepankan kepentingan manajer seringkali diklasifikasikan dalam perspektif oportunistik. Perspektif oportunistik ini pada gilirannya akan membebani pihak lain seperti para pemegang saham dan dikategorikan sebagai hal yang buruk. Manajemen laba dalam perspektif ini seringkali muncul dalam Bonus Plan. Di sisi lain, fenomena manajemen laba yang terus eksis dalam dunia bisnis karena perilaku ini memberikan manfaat. Manfaat dari manajemen laba ditengarai diperoleh jika manajer melakukan manajemen laba demi kepentingan entitas, khususnya pemegang saham. Fenomena ini banyak ditemui dalam hal political cost dan debt covenant. Penggunaan manajemen laba yang mengedepankan kepentingan perusahaan ini masuk dalam perspektif efisien. Dua sisi manajemen laba, yakni perspektif efisien dan perspektif oportunistik terjadi dalam banyak perusahaan. Usaha untuk menekan perilaku manajemen laba tentunya kemudian sedikit banyak harus memperhatikan dampak yang muncul atas 
perilaku tersebut, apakah dilakukan dalam kepentingan pribadi manajer atau untuk kepentingan entitas lebih

\section{DAFTAR PUSTAKA}

Ball, R., Brown, P. 1968. An Empirical Evaluation of Accounting Income Numbers. Journal of Accounting Research, Vol. 6: pp. 159-178.

Barth, M., Elliott, J. dan Finn, M. 1999. Market Rewards Associated With Patterns of Increasing Earnings. Journal of Accounting Research, Vol. 37: pp. 387-413.

Bartov, E., Givoly, D. dan Hayn, C. 2002. The Rewards to Meeting or Beating Earnings Expectations. Journal of Accounting and Economics, Vol. 33: pp. 173-204.

Beneish, M. 2001. Earnings Management: A Perspective. Managerial Finance, Vol.27: pp. 3-17.

Bernard, V. dan Stober, T. 1989. The Nature and Amount of Information in Cash Flows and Accruals. The Accounting Review, Vol. 64, pp: 624-652.

Boynton E. C., Dobbins S. P. dan Pleskott A.G.1992. Earnings Management and the Corporate Alternative Minimum Tax. Journal of Accounting Research, Vol. 30 Supplement.

Bradshaw, M.T., Richardson, S.A. dan Sloan, R.G. 2001. Do Analysts and Auditors Use Information in Accruals?. Journal of Accounting Research, Vol.39: pp. 45-74.

Brown, P. R. 1999. Earnings Management: A Subtle (and Troublesome) Twist to Earnings Quality. Journal of Financial Statement Analysis, Vol. 4: pp. 61-63.

Burgstahler, D. dan Dichev, I. 1997. Earnings Management to Avoid Earnings Decreases and Losses. Journal of Accounting and Economics, Vol 24, pp: 99-126.

Burgstahler, D. dan Eames, M. 1998. Management of Earnings and
Analysts' Forecasts to Achieve Zero and Small Positive Earnings Surprises. University of Washington Working Paper.

Cahan, S., 1992. The Effect of Antitrust Investigations on Discretionary Accruals: A Refined Test of The Political-Cost Hypothesis. The Accounting Review, Vol 67, pp: 7795.

Chaney, P. K. dan Lewis, C. M. 1995. Earnings Management and Firm Valuation Under Asymmetric Information. Journal of Corporate Finance, Vol. 1: pp. 319-345.

Chaney, P., Jeter, D., Lewis, C. 1998. The Use of Accruals in Income Smoothing: A Permanent Earnings Hypothesis. Advances in Quantitative Analysis of Finance \& Accounting, Vol 6: pp. 103 -135.

Christensen, T.E., Hoyt, R.E. dan Paterson, J.S. 1999. Ex Ante Incentives for Earnings Management and the Informativeness of Earnings. Journal of Business Finance and Accounting, Vol. 26: pp. 807-832.

Christie, A. dan Zimmerman, J. 1994. Efficient and Opportunistic Choice of Accounting Procedures: Corporate Control Contests. The Accounting Review, Vol. 69: pp. 539-566.

Cohen, D., Dey, A., Lys, T. 2008. Real dan Accrual-Based Earnings Management in The Pre- and PostSarbanes-Oxley periods. The Accounting Review, Vol. 83: pp. 757-787.

De Angelo, L. 1986. Accounting Numbers as Market Valuation Substitutes: A Study of Management Buyouts of Public Stockholders. The Accounting Review, Vol. 61: pp. 400-420.

De Angelo, L., and Skinner, J. 1994. Accounting Choice in Troubled Companies. Journal of Accounting and Economics, Vol.17: pp. 113143. 
Dechow Patricia M, Sloan Richard G dan Sweeney Amy P. 1996. Causes and Consequences of Earnings Manipulation: An Analysis of Firms Subject to Enforcement Actions by the SEC. Contemporary Accounting Research, Vol.13: Issue 1: pp. 1-36.

Dechow, P dan Skinner, D. 2000. Earnings Management: Reconciling the Views of Accounting Academics, Practitioners, and Regulators. Accounting Horizons, Vol.14: pp. 232-250.

Dechow, P. 1994. Accounting Earnings and Cash Flows as Measures of Firm Performance: The Role of Accounting Accruals. Journal of Accounting and Economics Vol. 18: pp. 3-42.

Dechow, P. dan Dichev, I. 2002. The Quality of Accruals and Earnings: The Role of Accrual Estimation Errors. The Accounting Review, Vol. 77: pp. 35-59.

Dechow, P., Kothari, S., Watts, R. 1998. The Relation Between Earnings and Cash Flows. Journal of Accounting and Economics, Vol. 25: pp. 133168.

Dechow, P.M, dan Sloan, R. 1991. Executive Incentives and The Horizon Problem, Journal of Accounting and Economics, Vol.14: pp. 51-89.

Demski, J. S., Patell, J. M. \& Wolfson, M. A. 1984. Decentralized Choice of Monitoring Systems. The Accounting Review, Vol.59: pp. 16-34.

Demski, J. 1998. Performance Measure Manipulation.

Contemporary Accounting Research, Vol.15: pp. 261- 285.

Dye Ronald A.1988. Earnings Management in An Overlapping Generation Model, Journal of Accounting Research, Vol 26: No. 2, pp: 195235.

Guay WR, Kothari S.P dan Watts R.L. 1996. A Market - Based Evaluation of
Discretionary Accruals Models. Journal of Accounting Research, Vol 34: pp. 83-109.

Healy Paul. M. 1985. The Effect of Bonus Schemes on Accounting Decisions. Journal of Accounting and Economics, Vol 7: pp. 85-107.

Healy, P. dan Palepu, K. 1990. Effectiveness of Accounting-Based Dividend Covenants. Journal of Accounting and Economic, Vol. 12: pp. 97-123.

Holthausen, R, W. and Leftwich, R. W. 1983, The Economic Consequence of Accounting Choice: Implications of Costly Contracting and Monitoring, Journal of Accounting and Economics, Vol. 5: pp. 77-117.

Holthausen, R. W. 1990. Accounting Method Choice: Opportunistic behaviour, Efficient Contracting and information Perspective. Journal of Accounting and Economics. Vol.12: pp. 207-218.

Holthausen, R., Larcker dan D., Sloan, R. 1995. Annual Bonus Schemes and The Manipulation of Earnings. Journal of Accounting and Economics. Vol.19: pp. 29-74.

Hunt, A., Moyer, S. dan Shevlin, T. 1997. Earnings Volatility, Earnings Management and Equity Value, Working Paper. University of Washington.

Jensen, M. C. 2001. Value Maximisation, Stakeholder Theory and The Corporate Objective Function. European Financial Management, Vol. 7:pp. 297-317.

Jensen, M.C. dan Meckling W.H.1976. Theory Of The Firm: Managerial Behavior, Agency Costs And Ownership Structure. Journal of Financial Economics, pp. 305-360.

Lev, B. 1989. On the Usefulness of Earnings and Earnings Research: Lessons and Directions From Two Decades of Empirical Research. Journal of 
Accounting Research, Vol. 27: pp. 153-20. Supplement

Lev, B. 2003. Corporate Earnings: Fact and Fiction. Journal of Economics Perspectives, Vol.17: pp. 27-50.

Ronen, J. dan Sadan, S. 1980, Accounting Classifications As a Tool for Income Prediction. Journal of Accounting, Auditing \& Finance, Vol. 3: pp. 339353.

Schipper, K. dan Vincent, L., 2003. Earnings Quality. Accounting Horizons, Vol.17: pp. 235-250.

Scott R William. 2003. Financial Accounting Theory, 3rd Edition, Prentice Hall.

Stocken, P. dan Verrecchia, R., 2004. Financial Reporting System Choice and Disclosure Management. The Accounting Review, Vol. 79: pp. 1181-1203.

Subramanyam, K. 1996. The Pricing of Discretionary Accruals. Journal of Accounting and Economics, Vol. 22: pp. 249-281.
Sweeney, A.P. 1994. Debt Covenant Violation and Managers' Accounting Response, Journal of Accounting and Economics, Vol. 17: pp. 281308.

Teoh, S., Wong, T. dan Rao, G. 1998. Are Accruals During Initial Public Offerings Opportunistic?. Review of Accounting Studies, 3, pp. 175-208.

Trueman, B dan S. Titman. 1988. An Explanation For Accounting Income Smoothing. Journal of Accounting Research, Vol. 26, Supplement, pp: 127-139.

Victor L. Bernard, Douglas J. Skinner, 1995. Annual Bonus Schemes and the Manipulation of Earnings. Journal of Accounting and Economics Vol. 19: pp. 29-74.

Watts Ross L. dan Zimmerman Jerold. 1978. Towards a Positive Theory of the Determination of Accounting Standards. The Accounting Review, Vol. 53. No. 1: pp. 131-156.

Watts, R.L., dan Jerold L. Zimmerman. 1986. Positive Accounting Theory. New Jersey, Prentice-Hall, Inc. 